\title{
PENGARUH PENERAPAN MODEL PEMBELAJARAN TEACHING FACTORY 6 LANGKAH (TF-6M) DAN PRESTASI BELAJAR KEWIRAUSAHAAN TERHADAP MINAT WIRAUSAHA
}

\author{
Rahmat Kurniawan \\ Program Studi Pendidikan Teknologi dan Kejuruan \\ Sekolah Pasca Sarjana Universitas Pendidikan Indonesia \\ J1. Dr. Setiabudhi 229 Bandung
}

\begin{abstract}
Abstrak. Model Pembelajaran Teaching Factory 6M merupakan model pembelajaran terpadu. Pendidikan kewirausahaan merupakan proses pembelajaran penanaman tata nilai kewirausahaan melalui pembiasaan dan pemeliharaan perilaku dan sikap. Melalui Model Pembelajaran Teaching Factory yang ditunjang dengan pembelajaran Kewirausahaan, diharapkan siswa mempunyai minat untuk berwirausaha. Penerapan Model Pembelajaran Teaching Factory bertujuan untuk membentuk kompetensi siswa melalui satuan kesatuan lingkungan sekolah dengan berbasis pada industri dan ditunjang dengan pelaksanaan pembelajaran Kewirausahaan dalam pembentukan mental kewirausahaan. Artikel ini menelaah pengaruh penerapan Model Pembelajaran Teaching Factory 6M dan prestasi belajar kewirausahaan terhadap minat wirausaha pada siswa Patiseri kelas XII SMKN 9 Bandung. Metode penelitian yang digunakan dalam penelitian ini adalah metode deskriptif dan verifikatif.
\end{abstract}

Kata kunci: model pembelajaran teaching factory 6 langkah, prestasi belajar kewirausahaan, minat wirausaha

\begin{abstract}
Teaching Factory 6M learning model is a comprehensive learning. Integrated with learning on enterpreneurship, the application of this model is expected to generate student's interest and achieving competence in enterpreneurship. This article discusses how the application of the Teaching Factory 6M learning model and student's achievement in enterpreneurship class effect student's interest in enterpreneurship. Employing descriptive and verificative methods, research was conducted to students of $12^{\text {th }}$ Grade Patisserie Program at SMKN 9 Bandung.
\end{abstract}

Keywords: teaching factory $6 \mathrm{~m}$ learning model, learning achievement in enterpreneurship, interest in enterpreneurship

\section{PENDAHULUAN}

Kurikulum dikembangkan atas dasar teori pendidikan berdasarkan standar dan teori pendidikan yang berbasis kompetensi. Pendidikan berdasarkan standar adalah pendidikan yang menetapkan standar nasional sebagai kualitas minimal hasil belajar yang berlaku untuk setiap kurikulum. Standar kualitas nasional dinyatakan sebagai Standar Kompetensi Lulusan. Standar Kompetensi Lulusan tersebut adalah kualitas minimal lulusan suatu jenjang atau satuan pendidikan yang mencakup sikap, pengetahuan, dan keterampilan (PP nomor 19 tahun 2005). Sementara itu, kompetensi mengacu pada Landasan Teoritis Kurikulum 2013 adalah kemampuan seseorang untuk bersikap, menggunakan pengetahuan dan 
keterampilan untuk melaksanakan suatu tugas di sekolah, masyarakat, dan lingkungan di mana yang bersangkutan berinteraksi.

Sekolah Menengah Kejuruan (SMK) merupakan pendidikan berjalur formal sebagai bentuk satuan pendidikan kejuruan. Sekolah Menengah Kejuruan menghasilkan lulusan yang memiliki kompetensi pada bidang keahliannya serta dapat dikembangkan dan siap memasuki dunia kerja. Program mata pelajaran di SMK pada prinsipnya terdiri dari tiga kelompok program mata pelajaran yaitu mata pelajaran normatif, adaptif, dan produktif. SMK harus mampu melaksanakan pembelajaran secara maksimal, tetapi fakta di lapangan menunjukkan, tidak semua SMK mampu menyelenggarakan proses pembelajaran dengan maksimal. Kondisi ini terjadi karena kurang maksimalnya keadaan sarana penunjang kegiatan praktikum serta penerapan model pembelajaran yang kurang dapat diterima siswa. Untuk itu diperlukan upaya untuk mengatasi keadaan ini; salah satunya melalui pengembangan model pembelajaran yang sesuai. Model pembelajaran yang dapat diterapkan adalah model pembelajaran Teaching Factory 6 Langkah yang selanjutnya biasa disebut dengan TF-6M.

Penerapan Model Pembelajaran TF-6M diharapkan dapat menunjang dalam upaya peningkatan sumber daya manusia yang inovatif dan kreatif di era globalisasi sekarang. Sumber daya manusia yang inovatif dan kreatif juga dapat diwujudkan melalui pendidikan kewirausahaan. Pendidikan kewirausahaan merupakan proses pembelajaran dan penanaman tata nilai kewirausahaan melalui pembiasaan dan pemeliharaan perilaku dan sikap. Pengertian kewirausahaan pada hakikatnya adalah sifat, ciri, dan watak seseorang yang memiliki kemauan dalam mewujudkan gagasan inovatif ke dalam dunia nyata secara kreatif (Suryana, 2000).

"Seseorang yang berminat untuk berwirausaha harus dapat menerima semua proses yang terjadi dalam wirausaha" (Purnama, 2009: 39). Melalui penerapan model pembelajaran TF-6M yang ditunjang dengan pembelajaran kewirausahaan, diharapkan siswa mempunyai minat untuk berwirausaha. Individu (siswa) harus mampu mempersiapkan bekal berupa sikap mental dan belajar untuk menguasai beberapa keterampilan yang menunjang pelaksanaan wirausaha. 
Model TF-6M terdiri dari dua kelompok kegiatan softskill dan hardskill yang bertujuan meningkatkan kompetensi siswa dalam mata pelajaran produktif kompetensi keahlian. Kegiatan softskill dan hardskill diharapkan mampu mengembangkan potensi siswa dalam bentuk kecakapan personal, sosial, akademik dan vokasional yang terpadu pada siklus pembelajaran. Terdapat tiga unsur yang terlibat dalam proses pembelajaran, yaitu : siswa yang memerankan sebagai pekerja, guru yang berperan sebagai asesor, konsultan, fasilitator, dan sekaligus sebagai penanggungjawab keseluruhan program pembelajaran, dan pemberi/pemilik pesanan/pemesan baik dari industri, dari perorangan atau dari sekolah setempat (Martawijaya 2010).

Model Pembelajaran TF-6M dalam satu siklus kerja terdiri dari enam langkah yaitu: menerima pemesan, menganalisis pesanan, menyatakan kesiapan mengerjakan pesanan, mengerjakan pesanan, melakukan kontrol kualitas, dan menyerahkan pesanan.

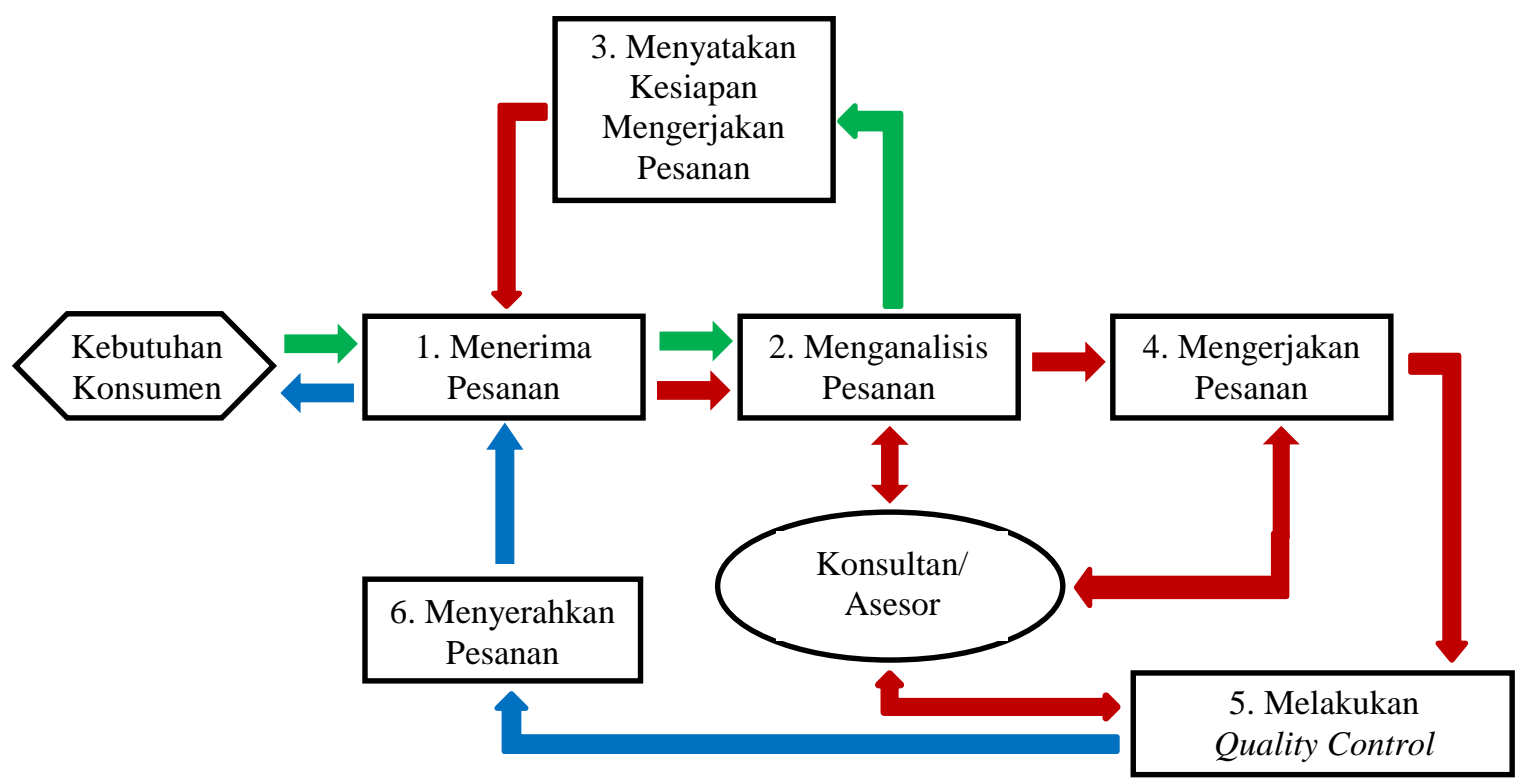

Sumber : Martawijaya D. H. 2010

Gambar 1. Alur Pelaksanaan Model Pembelajaran TF-6M

Kompetensi Keahlian Patiseri merupakan bagian dari Program Keahlian Tata Boga sebagai program keahlian yang berkomitmen melahirkan tenaga-tenaga didik yang memiliki keterampilan, keahlian, dan profesionalisme di bidang kuliner. Tujuan kompetensi keahlian Patiseri secara umum mengacu pada isi Undang-Undang Sistem Pendidikan Nasional (UU SPN) pasal 3 mengenai Tujuan 
Pendidikan Nasional dan penjelasan pasal 15 yang menyebutkan bahwa pendidikan kejuruan merupakan pendidikan menengah yang mempersiapkan peserta didik terutama untuk bekerja dalam bidang tertentu. Secara khusus, tujuan kompetensi keahlian Patiseri adalah membekali peserta didik dengan keterampilan, pengetahuan, dan sikap agar kompeten dalam:

1. Menerapkan keselamatan, kesehatan kerja (K3) dan higinie sanitasi

2. Melakukan komunikasi dalam pelayanan jasa

3. Melakukan persiapan pengelolaan.

4. Mengolala kue Indonesia

5. Mengolaah kue pastry kontinental

6. Menyiapkan coklat dan permen coklat

7. Membuat produk roti dan kue untuk diet khusus

8. Melakukan pelayanan makanan dan minuman

9. Membuat hidangan penutup

10. Melakukan pengelolaan usaha produk patiseri

Pendidikan kewirausahaan adalah suatu disiplin ilmu yang mempelajari tentang nilai, kemampuan, dan perilaku seseorang dalam menghadapi tantangan hidup untuk memperoleh peluang dengan berbagai resiko yang mungkin dihadapinya. Pendidikan tersebut menjadi dasar bagi siswa untuk menjadi seorang wirausaha yang memiliki pengetahuan tentang kewirausahaan. Sekolah telah bekerja keras untuk mengupayakan pembaharuan pendidikan. Sekolah dihadapkan pada suatu tantangan dan tuntutan jaman, dimana SMK harus berusaha mewujudkan manusia-manusia wirausaha di lingkungan sekolah. Para siswa yang belajar di SMK bukan saja dituntut untuk mengejar angka-angka yang tinggi dan prestasi intelektualnya, namun juga harus mengejar nilai-nilai moral, sikap mental wirausaha, kepekaan terhadap arti lingkungan, fakta-fakta dan pengetahuan fungsional, dan keterampilan wirausaha yang menuntut penciptaan perubahan.

Mata pelajaran kewirausahaan di SMK bertujuan agar peserta didik memiliki kemampuan sebagai berikut:

a. Memahami dunia usaha dalam kehidupan sehari-hari

b. Berwirausaha dalam bidangnya

c. Menerapkan perilaku kerja prestatif dalam kehidupannya 
d. Mengaktualisasikan sikap dan perilaku wirausaha

\section{METODOLOGI PENELITIAN}

Metode penelitian yang digunakan adalah metode kuantitatif. Analisis penelitian digunakan studi deskriptif yaitu metode yang diarahkan untuk memecahkan masalah dengan cara memaparkan atau menggambarkan apa adanya hasil penelitian. Fokus penelitian pada pengaruh variabel bebas terhadap variabel terikat dengan teknik analisis statistik inferensial. Sugiono (2004: 170) mengungkapkan bahwa statistik inferensial adalah teknik statistik yang dipakai untuk menganalisis data sampel kemudian hasilnya diberlakukan untuk populasi

Penelitian kuantitatif banyak digunakan untuk menguji teori, fakta, mendeskripsikan statistik, dan menunjukkan hubungan antar variabel. Penelitian bersifat mengembangkan konsep, mengembangkan pemahaman atau mendeskripsikan fakta di lapangan.

\section{PEMBAHASAN}

\section{Penerapan Model Pembelajaran TF-6M sebagai Variabel $\mathrm{X}_{1}$}

Data kuantitaf diperolah melalui penyebaran angket/instrument yang ditujukan pada persepsi siswa tentang penerapan model pembelajaran TF-6M. Instrumen persepsi model pembelajaran TF-6M dianggap mewakili dalam memperoleh data penerapan model pembelajaran TF-6M. Berdasarkan hasil perhitungan distribusi frekuensi dan perhitungan statistik dasar $\left(\mathrm{X}_{1}\right)$ diperoleh hasil data sebagai berikut: Banyak kelas $(\mathrm{bk})=5,31 \approx 5$ panjang kelas $=5,16 \approx 5$, $\mathrm{n}($ sampel $)=30$, jumlah $\left(\sum \mathrm{X}_{1}\right)=2685$, rata-rata $\left(\sum \mathrm{X}_{1} / \mathrm{n}\right)=89,50$, simpangan baku $(S)=8,50$, skor terendah $=75$, skor tertinggi $=102$, $\operatorname{modus}=97$, median $=90$.

Mayoritas responden persepsi siswa tentang TF-6M ( $\left.\mathrm{X}_{1}\right)$ sebanyak 20 orang atau $67 \%$ dan tergolong ke dalam karakteristik sedang sebanyak 10 orang atau 33\%. Apabila dimaknai dari data yang didapat dengan mencari rata-rata responden yaitu sebesar 89,50. Instrumen hasil penelitian persepsi siswa tentang model pembelajaran TF-6M dengan mengacu pada karakteristik persepsi, adalah berkarakter sedang. Mengandung arti bahwa siswa memiliki persepsi yang 
antusias terhadap penerapan model pembelajaran TF-6M pada bidang patiseri, akan tetapi siswa masih perlu banyak latihan dan pembiasaan terhadap model pembelajaran TF-6M.

\section{Prestasi Belajar Kewirausahaan sebagai Variabel $X_{2}$}

Berdasarkan data nilai prestasi belajar yang diperoleh dari sekolah maka penulis melakukan pengkarakteiristikan dengan cara menjumlahkan skor, kemudian dicari panjang interval. Hasil perhitungan distribusi frekuensi dan perhitungan statistik dasar $\left(\mathrm{X}_{2}\right)$ diperoleh hasil data sebagai berikut: Banyak kelas $(\mathrm{bk})=5,39 \approx 5$ panjang kelas $=2,40 \approx 2, \mathrm{n}($ sampel $)=30$, jumlah $\left(\sum \mathrm{X}_{2}\right)=2412$, $\operatorname{rata} \operatorname{rata}\left(\sum \mathrm{X}_{2} / \mathrm{n}\right)=80,40$, simpangan $\operatorname{baku}(\mathrm{S})=4,27$, skor terendah $=73$, skor tertinggi $=87$, modus $=78$, median $=80$. Mayoritas responden tentang prestasi belajar kewirausahaan $\left(\mathrm{X}_{2}\right)$ tergolong dalam karakteristik baik yakni sebanyak 30 orang atau $100 \%$. Data yang didapat dengan mencari rata-rata responden yaitu sebesar 80,40. Dimaknai prestasi belajar siswa pada mata pelajaran kewirausahaan adalah berkarakter baik. Mengandung arti bahwa siswa memiliki daya tangkap pemahaman yang baik, dari segi kognitif dan psikomotor. Ditunjang juga dengan perilaku siswa yang baik ditunjukkan selama kurun waktu pembelajaran berlangsung.

\section{Minat Wirausaha sebagai Variabel $\mathbf{Y}$}

Gambaran mengenai minat wirausaha, Hasil perhitungan distribusi frekuensi dan perhitungan statistic dasar $\left(\mathrm{X}_{1}\right)$ diperoleh hasil data sebagai berikut: Banyak kelas $(\mathrm{bk})=5,13 \approx 5$, panjang kelas $=15,6 \approx 16, \mathrm{n}($ sampel $)=30$, jumlah $\left(\sum \mathrm{X}_{1}\right)=1964$, rata-rata $\left(\sum \mathrm{X}_{1} / \mathrm{n}\right)=65,467$, simpangan baku $(\mathrm{S})=21,104$, skor terendah $=21$, skor tertinggi $=99$, modus $=55$, median $=69$.

Mayoritas tanggapan responden tentang minat wirausaha (Y) tergolong dalam karakteristik sangat tinggi yakni sebanyak 9 orang atau 30\%. Sementara itu frekuensi terkecil yaitu dengan karakteristik sedang sebanyak 4 orang atau $13 \%$. Data yang didapat dengan mencari rata-rata responden yaitu sebesar 65,47. Dimaknai prestasi belajar siswa pada mata pelajaran kewirausahaan adalah berkarakter sedang. Mengandung arti minat siswa untuk melakukan wirausaha sudah ada hanya masih terus perlu dilakukan upaya pengarahan lebih baik lagi. 
Sebagian dari siswa masih berharap dapat bekerja pada perusahaan orang lain dibandingkan dengan memiliki usaha sendiri.

\section{Penerapan Model Pembelajaran TF-6M sebagai Variabel $\mathrm{X}_{1}$}

Hasil data mengindikasikan bahwa ketertarikan siswa terhadap model pembelajaran TF-6M lebih besar dibandingkan dengan model pembelajaran konvensional. Instrumen yang diberikan kepada siswa mengenai persepsi siswa tentang model pembelajaran TF-6M didapat data bahwasanya siswa lebih merasa mudah dalam memahami pembelajaran produktif. Siswa dilibatkan langsung dalam pembuatan produk sekaligus dalam kegiatan pemasaran. Sehingga dalam kegiatan pembelajaran ini siswa akan dihadapkan pada sikap bertanggung jawab dalam bekerja, untuk kompeten dalam produktifitasnya.

\section{Prestasi Belajar Kewirausahaan sebagai Variabel $\mathbf{X}_{2}$}

Data prestasi belajar kewirausahaan memberikan gambaran, bahwa pendidikan kewirausahaan perlu upaya pendekatan kegiatan pembelajaran yang lebih menarik. Pendidikan kewirausahaan dipandang perlu dimiliki oleh siswa terlebih siswa SMK sebagai bekal pengetahuannya. Baik pada saat bekerja di industry, terlebih lagi ketika akan merintis usaha sendiri.

\section{Minat Wirausaha sebagai Variabel $Y$}

Data mengenai minat wirausaha siswa mayoritas tanggapan responden tentang minat irausaha $(\mathrm{Y})$ tergolong dalam karakteristik sangat tinggi yakni sebanyak 9 orang atau 30\%. Sementara itu rata-rata responden tentang minat wirausaha termasuk ke dalam karaktersitik sedang yakni sebanyak 65,47\%. Kondisi ini dipengaruhi oleh beberapa faktor. Pandangan masyarakat mengenai profesi wirausaha dewasa ini mulai diminati. Kebutuhan masyarakat akan dunia kerja yang kurang mampu terserap oleh industri, menjadikan masyarakat berfikir lebih kreatif untuk memanfaatkan peluang yang ada untuk berwirausaha.

\section{Pengaruh Penarapan Model Pembelajaran TF-6M sebagai Variabel $X_{1}$ terhadap Minat Wirausaha sebagai Variabel Y}

Berkaitan dengan hasil pengolahan data ini menunjukkan bahwa penerapan model pembelajaran TF-6M memberikan pengetahuan dan pengalaman langsung siswa mengelola usaha bidang patiseri. Pengetahuan dan pengalaman tersebut telah menumbuhkan minat wirausaha siswa, khususnya dalam bidang patiseri. 


\section{Pengaruh Prestasi Belajar Kewirausahaan sebagai Variabel $X_{2}$ terhadap Minat Wirausaha sebagai Variabel Y}

Variabel prestasi belajar Kewirausahaan $\left(\mathrm{X}_{2}\right)$ memberikan pengaruh terhadap minat wirausaha (Y) hanya sebesar 0,049. Hasil pengolahan memberikan gambaran proses pembelajaran Kewirausahaan hanya sedikit saja menumbuhkan minat wirausaha siswa. Kondisi yang terjadi sebenarnya siswa mengikuti segala tugas pemasaran pada mata pelajaran kewirausahaan hanya untuk gugur tugas saja. Siswa melakukan latihan penjualan hanya sebatas produk dapat habis terjual. Kebanyakan dari siswa melakukan proses pemasaran produk kepada keluarganya, termasuk kepada orang tuanya.

\section{Pengaruh Penerapan Model Pembelajaran TF-6M sebagai Variabel $\mathrm{X}_{1}$ dan Prestasi Belajar Kewirausamaan sebagai Variabel $X_{2}$ terhadap Minat Wirausaha sebagai Variabel Y}

Kedua varibel bebas secara bersamaan memberikan pengaruh yang signifikan terhadap variabel terikat sebesar 0,656. Hasil pengolahan data ini memberikan gambaran minat wirausaha dapat terbentuk melalui proses pembiasaan dengan dimbangi pengetahuan yang baik tentang kewirausahaan. Siswa mendapatkan pembiasaan salah satunya melalui penerapan model pembelajaran TF-6M. Penerapan model pembelajaran TF-6M telah memberikan pengalaman langsung bagi siswa melalui kegiatan pembelajaran dengan atmosfer seperti di industri. Di samping itu, untuk menguatkan pengetahuan tentang kewirausahaan siswa mendapatkannya melalui kegiatan pembelajaran Kewirausahaan. Melalui mata pelajaran Kewirausahaan siswa dibekali pengetahuan mengenai wirausaha.

\section{KESIMPULAN}

Kesimpulan penelitian disusun berdasarkan pembahasan hasil penelitian yang mengacu pada tujuan penelitian, disimpulkan sebagai berikut :

1. Penerapan model pembelajaran TF-6M melalui angket persepsi siswa tentang penerapan model pembelajaran TF-6M berada pada kategori sedang.

2. Prestasi belajar kewirausahaan melaui data peroleh hasil belajar murni sebelum dilakukan program remedial berada pada kategori baik. 
3. Minat wirausaha melalui angket minat wirausaha, memberikan gambaran tentang minat wirausaha siswa berada pada kategori sedang

4. Hasil penelitian menunjukkan pengaruh penerapan model pembelajaran TF$6 \mathrm{M}$ yang signifikan terhadap minat wirausaha.

5. Hasil penelitian menunjukkan adanya pengaruh prestasi belajar kewirausahaan terhadap minat wirausaha.

6. Secara bersama-sama terdapat pengaruh yang signifikan penerapan model pembelajaran TF-6M dan prestasi belajar kewirausahaan terhadap minat wirausaha.

\section{DAFTAR PUSTAKA}

Ali M. (1983). Prosedur Penelitian. Bandung: Sinar Algesindo

Alma B. (2002). Kewirausahaan. Bandung: Alfabet (2008). Kewirausahaan. Bandung: Alfabet

Alwi H. (2001). Kamus Besar Bahasa Indonesia. Jakarta: Pusat Bahasa Depdiknas

Arikunto S. (2002). Prosedur Penelitian Suatu Pendekatan Praktek. Jakarta : Rineka Cipta

Djamarah, S.B. dan Zain, A. (2002). Strategi Belajar Mengajar. Jakarta: Rineka Cipta.

Bartono. (2006). Tata Boga Internasional. Yogyakarta: CV Nur Cahaya.

Burger, Kurt dan Getraud, B. (1999). Pengetahuan dan Pengolahan Makanan. Austria: Percetakan Buku Sekolah Turner

Departemen Pendidikan dan Kebudayaan. (2002). Kamus Besar Bahasa Indonesia. Jakarta : Balai Pustaka

Dimyati dan Mudjiono. (2002). Belajar dan Pembelajaran. Jakarta : Rineka Cipta

Djamarah, S.B. dan Zain, A. (2002). Strategi Belakar Mengajar. Jakarta : Rineka Cipta

Hamalik O. (2000). Ilmu Budaya Dasar. Jakarta: Bumi Aksara

Hasan B. (2010). Cara Praktis Membangun Wirausaha. Bandung: Pustaka Ramadhan

Himpunan Peraturan Perundangan-undangan. (2003). UU RI No. 20 Tahun 2003, Tantang Sistem Pendidikan Nasional (SISDIKNAS) 2003 Beserta Penjelasannya. Bandung: Fokusmedia

Komar O. (2006). Filsafat Pendidikan Non Formal. Bandung: Grafika

Kurikulum SMK. (2012). Dokumen Kurikulum 2013. Kemendikbud. 
Kusnendi. (2008). ModeL-Model Persamaan Stuktural. Bandung: Penerbit Alfabeta

Martawijaya D.H. (2010). Implementasi Model Pembelajaran Teaching Factory Enam Langkah untuk Meningkatkan Kompetensi Produktif Siswa SMK Pariwisata. Bandung: FPTK UPI

Ropke J. (1995). Ekonomi Koperasi, Teori dan Manajemen. Jakarta: Salemba Empat

Sagala S. (2007). Konsep dan Makna Pembelajaran. Bandung: Alfabeta

Sardiman. AM. (2001). Minat dan Motivasi. Jakarta: Rineka Cipta. 